\title{
Pectin Degradation in Fruit Juices by Pectinase from Meyerozyma sp. VITPCT75 Isolated from Phyllanthus emblica
}

\author{
B. Meena, V.G. Sowmeya, Archa B. Praveen, A. Swetha, \\ D. Naga Sarath Chandra and M. Kavitha* (D)
}

School of Biosciences and Technology, Vellore Institute of Technology, Vellore - 632 014, Tamilnadu, India.

\begin{abstract}
This study aimed to identify and characterize a pectinase-producing novel yeast from the fermented juice of Phyllanthus emblica and apply the enzyme for fruit juice clarification. Among the five pectinaseproducing yeasts, isolate-1 exhibited the highest pectinase activity and was further used in this study. Based on morphological, physiological, and 18SrRN Aanalyses, isolate-1 was recognized as a new strain sharing $99 \%$ sequence homology with other Meyerozyma strains and was thus designated as Meyerozyma sp. VITPCT75. The strain produced pectinase optimally at a temperature and $\mathrm{pH}$ of $25^{\circ} \mathrm{C}$ and 7, respectively. Maximum pectinase production was observed after 4-days incubation. The enzyme exhibited optimum activity at the temperature of $25^{\circ} \mathrm{C}$ and $\mathrm{pH}$ 7.0. The enzyme was more stable at a temperature and $\mathrm{pH}$ of $20^{\circ} \mathrm{C}$ and 7 , respectively. Storage stability studies revealed that the enzyme was stable at $-20^{\circ} \mathrm{C}$. The cell-free supernatant was partially purified using ammonium sulfate and solvent precipitation. Acetone at a concentration of $20 \%$ assured an adequate partial purification. The molecular weight of pectinase was determined as $6 \mathrm{kDa}$. The enzymatic metal ion preference-related studies revealed that $\mathrm{Ca}^{2} \mathrm{z}, \mathrm{Kz}, \mathrm{Cu}^{2} \mathrm{z}, \mathrm{Fe}^{2} \mathrm{z}$, and $\mathrm{Ba}^{2} \mathrm{z}$ ions enhanced, $\mathrm{Ni}^{2} \mathrm{z}$ ions moderately inhibited, and $\mathrm{Mn}^{2} \mathrm{z}$ ions intensely inhibited the enzymatic activity. Neither $\mathrm{Na}^{+}$and $\mathrm{Mg}^{2+}$ ions nor EDTA affected the enzyme activity. When subjected to fruit juice clarification, the enzyme significantly reduced the viscosity of the juice.
\end{abstract}

Keywords: Pectinase, Pectin, Meyerozyma sp., Phyllanthus emblica, Psychrophilic

*Correspondence: mkavitha1972@gmail.com

(Received: January 19, 2021; accepted: May 27, 2021)

Citation: Meena B, Sowmeya VG, Praveen AB, Swetha A, Chandra DNS, Kavitha M. Pectin Degradation in Fruit Juices by pectinase from Meyerozyma sp. VITPCT75 Isolated from Phyllanthus emblica. J Pure Appl Microbiol. 2021;15(2):926-935. doi: 10.22207/ JPAM.15.2.51

(C) The Author(s) 2021. Open Access. This article is distributed under the terms of the Creative Commons Attribution 4.0 International License which permits unrestricted use, sharing, distribution, and reproduction in any medium, provided you give appropriate credit to the original author(s) and the source, provide a link to the Creative Commons license, and indicate if changes were made. 


\section{INTRODUCTION}

Pectinases (EC 3.2.1.15) (polygalaturonases) are hydrolytic enzymes that cleave the $\beta-1,4$ glycosidic bonds linking galacturonic acids in pectin present in the plant cell walls $\mathbf{s}^{1,2}$. Pectinases play a vital role in the usual ripening processes of certain fruits by altering the nature of pectin substances ${ }^{3,4}$. They are extensively used in the food industry, plant tissue maceration, degumming of natural fibers, textiles, and wastewater treatment ${ }^{5,6}$. In the food industry, they are used for fruit juice clarification, pesticide fermentation, and essential oil extraction ${ }^{7}$. Moreover, pectinases improve liquefaction, clarification, filterability, color release, and flavor compounds from the fruits into boost wine quality ${ }^{8}$. Pectinases of microbial origin are classified into enzymes with depolymerizing and saponifying activities. Polymethyl galacturonases, pectin lyases, pectate lyases, and polygalacturonases are depolymerizing enzymes, whereas pectin esterases are saponifying enzymes ${ }^{9}$.

Microbes are the best enzyme sources, allowing an economical advantage with low resource consumption, fewer by products, no toxicity, no requirement of rare and expensive elements, and low emissions involving no social and political issues ${ }^{10,11}$. Microbial enzymes are preferred in the industry due to their wide spectrum of working conditions, better performance, and feasibility for scale-up by genetic modifications ${ }^{12}$. Traditionally, pectinases are obtained from yeast, filamentous fungi, and bacteria. Fungi commonly produce a mixture of enzymes and release methanol as a by product. Yeasts are always preferred for pectinase production as they are unicellular, exhibit simple growth requirements, and are inducer-independent with the ease of genetic manipulations ${ }^{13,14}$. Above all, they do not secrete pectin methylesterase and, hence, pectinases could preferably be used to clarify fruit juices and wine without the risk of methanol fermentation ${ }^{15,16}$. Yeasts generally exhibit short growth and fermentation cycles and are GRAS organisms. Therefore, they could be used safely and efficiently in the food industry. Yeasts could also be immobilized and used for continuous fermentation.

Studies have already focused on yeast-derived pectinases of several genera as
Saccharomyces, Cryptococcus, Kluyveromyces, Aureobasidium, Rhodotorola, and Candida ${ }^{17,20}$. Alkaline pectinases are generally produced by bacteria, filamentous fungi, and yeasts ${ }^{21,22}$. Yeast-derived pectinases are commonly active at acidic $\mathrm{pH}$ of 4-6, although certain pectinases are also active at neutral $\mathrm{pH}^{23,24}$. Fruit dumped soil and spoilt refrigerated fruits are also good sources of pectinolytic microorganisms. In a recent study, pectinase-producing microorganisms were isolated from coffee bean samples ${ }^{25}$. In another report, pectinase-producing Bacillus sp. was isolated from cassava waste ${ }^{26}$. At present, research efforts are focused on the identification of novel microbial pectinases with desirable biochemical and physicochemical characteristics from diverse ecosystems for commercial applications, considering the potential applications of pectinases in the food sector. The present study was carried out to isolate and characterize pectinase-producing novel yeast strains from fermented Phyllanthus emblica (gooseberry) juice to explore the potential of the produced enzymes in fruit juice clarification. To the best of our knowledge, this is the first report of a novel, pectinase-producing yeast strain Meyerozyma sp. derived from Phyllanthus emblica fruits. This study describes partial purification and characterization of pectinase and its ability to clarify fruit juices.

\section{MATERIALS AND METHODS Materials}

D-Galacturonic acid sodium salt was procured from Sigma Chemicals. The culture media ingredients were purchased from Hi-Media, Mumbai. The protein molecular weight markers were purchased from Merck. All other chemicals used were of analytical grade.

\section{Pectinase-producing yeast strain isolation and identification \\ Phyllanthus emblica fruits were obtained} from a local market and authenticated by a botanist. Well-matured and ripe fruits were selected, surface-sterilized, cut into pieces, crushed, and incubated at room temperature for 4 days for natural fermentation. The fermented juice thus obtained was used to screen for pectinaseproducing yeast, which was screened based on the utilization of pectin as the only carbon source in the screening medium, yeast extract peptone 
pectin agar (YPPA) containing (g/l) yeast extract 10 , peptone 20, pectin 20, and agar $20^{27}$. Fermented fruit juice samples were serially diluted in sterile water, and aliquots were plated on YPPA using the spread plate technique. The plates were incubated at $25^{\circ} \mathrm{C}$ for $48 \mathrm{~h}$. Yeast colonies with a characteristic creamy appearance were selected and sub-cultured on YPP, isolate-1 was identified as a potential pectinase-producing yeast based on the pectinase assay and selected for further study. Species identification of isolate-1 was identified based on its morphological, physiological, and molecular features. The $18 \mathrm{~S}$ rRNA gene of the strain was partially amplified using universal ITS primers, and the 5.8 rRNA gene was completely amplified. The sequences were deposited at NCBI with accession number $\mathrm{MH} 217580$, and further studies were performed using the NCBI server (http://www.ncbi.nlm.nih.gov) using the BLAST (BLASTN) tool, and a phylogenetic tree was created.

\section{Pectinase assay and protein estimation}

The production medium for pectinase was composed of $(\mathrm{g} / \mathrm{l})$ yeast extract 10 , peptone 20 , and pectin 20 , and $\mathrm{pH} 7$. The sterilized medium was seeded with active inoculum (10\%) and incubated at $25{ }^{\circ} \mathrm{C}$ under shaking conditions (180 rpm) for four days. The culture fluid was centrifuged at $8000 \mathrm{rpm}$ for $15 \mathrm{~min}$. and $4{ }^{\circ} \mathrm{C}$ ) to obtain the supernatant for further study. Polygalacturonase/ pectinase activity was calculated by measuring the concentration of reducing sugar using the modified dinitrosalicylic acid(DNS) method using pectin as the substrate ${ }^{28}$. Pectinase acts on pectin and releases galacturonic acid, which reduces DNS to amino nitrosalicylic acid with $\lambda$ max of $540 \mathrm{~nm}$. D-galacturonic acid was used as the standard in the assay. One unit of pectinase activity was specified as the quantity of enzyme needed to liberate $1 \mu \mathrm{M}$ galacturonic acid per $\mathrm{ml}$ per min under prescribed conditions of the assay. Protein was estimated by Lowry's method using BSA as a standard ${ }^{29}$.

\section{Partial pectinase purification}

The protein fraction of the supernatant was enriched by precipitation using ammonium sulfate, acetone, and ethanol. Ten milliliters of the supernatant was exposed to 20, 30, 40, 50, 60, 70, and $80 \%$ saturation and centrifuged (10000 rpm, $20 \mathrm{~min}$, and $4^{\circ} \mathrm{C}$ ) to derive the precipitates, which were then dissolved in $1 \mathrm{ml}$ of sodium phosphate buffer ( $\mathrm{pH}$ 7). Pectinase and specific activity were evaluated at all saturation points. To purify the enzyme further by ion-exchange chromatography, a $\mathrm{pH}$ survey was performed, and it was observed that a $\mathrm{pH}$ of 6.5 was ideal for pectinase in the DEAE Sephadex ion exchanger. A DEAES ephadex $(20 \mathrm{~cm}$ $\times 1 \mathrm{~cm}$ ) column was pre-equilibrated with $0.01 \mathrm{M}$ sodium phosphate buffer ( $\mathrm{pH}$ 6.5). Five milliliters of the acetone precipitate was injected, and the column was rinsed with buffer continuously (flow rate of $60 \mathrm{ml} \mathrm{h}^{-1}$ ). The bound protein fractions were eluted with $\mathrm{NaCl}$ (linear gradient, 0.02-1.0 $\mathrm{M})$. Fractions rich in pectinase were combined, enriched further, and stored at $-20^{\circ} \mathrm{C}$.

\section{SDS-PAGE}

The molecular size of pectinase from isolate-1 was assessed by SDS-PAGE using a $12 \%$ polyacrylamide gel ${ }^{30}$. Carbonic anhydrase (29 kDa), ovalbumin (43 kDa), bovine serum albumin (66 $\mathrm{kDa})$, and phosphorylase-B (97.4 kDa) were used as molecular weight markers.

\section{pH effect and stability}

The effect of $\mathrm{pH}$ on pectinase activity was ascertained by performing the assay at various $\mathrm{pH}$ values(4.5-9). For this experiment, $0.05 \mathrm{M}$ acetate, phosphate, and Tris- $\mathrm{HCl}$ buffers (pH 4.5-6, 6-7,

Table 1. Morphological and sugar fermentation characteristics of Meyerozyma sp. VITPCT75

\begin{tabular}{lll}
\hline S. No. & Test & Observation \\
\hline 1 & Simple staining & Oval budding yeast cells \\
2 & Lactophenol cotton blue staining & Oval budding yeast cells \\
3 & Sugar fermentation & \\
& i). Glucose & Positive with gas \\
& ii). Sucrose & Positive with gas \\
& iii). Lactose & Negative
\end{tabular}




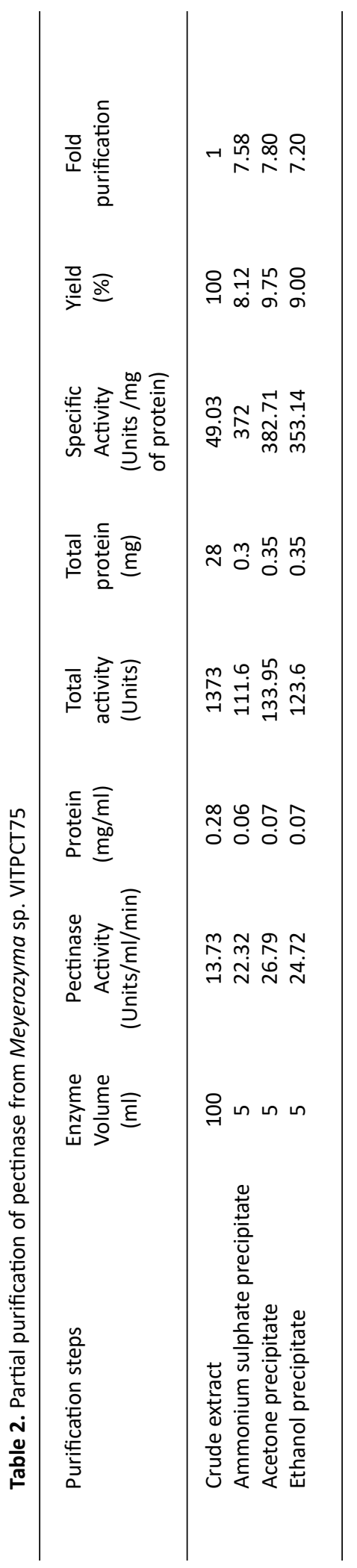

Journal of Pure and Applied Microbiology and 8-9, respectively) were used. The stability of pectinase at different $\mathrm{pH}$ values was analyzed by keeping the enzyme suspensions in the $\mathrm{pH}$ range of 6-8 for up to $16 \mathrm{~h}$. Aliquots were collected at $0.5,1,2,4,8$, and $16 \mathrm{~h}$, and the pectinase activity was calculated at $\mathrm{pH} 7$.

\section{Temperature effect and thermal stability}

The effect of temperature on pectinase activity was investigated by incubating the reaction mixture in the range of $15-80^{\circ} \mathrm{C}$. The stability of the enzyme at different holding temperatures was scrutinized by incubating the enzyme suspensions at $20,30,40$, and $50^{\circ} \mathrm{C}$. Specimens were obtained at $0.5,1,2,4,8$, and $16 \mathrm{~h}$, and the pectinase activity was calculated at $\mathrm{pH} 7$ and $25^{\circ} \mathrm{C}$.

Storage stability

The storage stability of pectinase was evaluated at storage temperatures of $25^{\circ} \mathrm{C}$ (room temperature), $4{ }^{\circ} \mathrm{C}$ (cold), and $-20^{\circ} \mathrm{C}$ (frozen). The suspension was held at the respective temperatures at a constant $\mathrm{pH} 7$ for 10 days. Representative specimens were acquired at $48 \mathrm{~h}$ intervals, and the remaining pectinase activity was quantified.

\section{Metal ion and inhibitor effects}

The effects of metal ions and specific inhibitors on pectinase were reviewed by exposing the suspension to representative metal ions and specific inhibitors at $25^{\circ} \mathrm{C}$ for $1 \mathrm{~h}$ with appropriate controls. Persisting pectinase activity was then determined.

Fruit juice clarification

The food industry is the largest consumer of pectinases, where the enzyme is used to degrade suspended pectin in order to improve the quality and efficiency of fruit juices. To appraise the suitability of pectinase from isolate-1, a study on its ability to identify representative fruit juices was undertaken. Fresh fruits were procured from the local market, and raw juice was obtained after tissue grinding and pressing. Partially purified pectinase from isolate-1, containing 10 units $/ \mathrm{ml} /$ min of enzyme, was used in this study. Fruit juice ( $50 \mathrm{ml}$ of fruit juice was mixed with $10 \mathrm{ml}$ of enzyme extract and incubated at $25^{\circ} \mathrm{C}$ for $1 \mathrm{~h}$ along with the control (without enzyme) to allow pectinase to degrade pectin. After incubation, the mixture was kept in a boiling water bath for $10 \mathrm{~min}$ and centrifuged at $8000 \mathrm{rpm}$ for $15 \mathrm{~min}$ at $4{ }^{\circ} \mathrm{C}$. The 
supernatant was saved, and its viscosity was measured in a Tech-ED viscometer ${ }^{7,31}$. The results were then recorded.

The experiments were performed in duplicates. Pectinase assays were performed in duplicate and repeated twice. The values

Table 3. Effect of metal ions, detergents and specific inhibitors on pectinase

\begin{tabular}{|c|c|c|}
\hline & Concentration & $\begin{array}{c}\text { Relative } \\
\text { Activity (\%) }\end{array}$ \\
\hline \multicolumn{3}{|l|}{ Metal Salts } \\
\hline $\mathrm{CaCl}_{2}$ & $1 \mathrm{Mm}$ & 120 \\
\hline $\mathrm{CaCl}_{2}^{2}$ & $10 \mathrm{Mm}$ & 177 \\
\hline $\mathrm{MnCl}_{2}$ & $1 \mathrm{Mm}$ & 12 \\
\hline $\mathrm{CoCl}_{2}^{2}$ & $1 \mathrm{mM}$ & 125 \\
\hline $\mathrm{NiCl} 2$ & $1 \mathrm{mM}$ & 78 \\
\hline $\mathrm{NaCl}$ & $10 \mathrm{mM}$ & 126 \\
\hline $\mathrm{NaCl}$ & $1 \mathrm{mM}$ & 106 \\
\hline $\mathrm{KCl}$ & $1 \mathrm{mM}$ & 131 \\
\hline $\mathrm{CuSO}_{4}$ & $1 \mathrm{mM}$ & 130 \\
\hline $\mathrm{FeSO}_{4}$ & $1 \mathrm{mM}$ & 136 \\
\hline $\mathrm{MgCl}_{2}^{4}$ & $1 \mathrm{mM}$ & 96 \\
\hline $\mathrm{BaCl}_{2}^{2}$ & $1 \mathrm{mM}$ & 138 \\
\hline Sodium citrate & $1 \mathrm{mM}$ & 125 \\
\hline EDTA & $1 \mathrm{Mm}$ & 131 \\
\hline EDTA & $10 \mathrm{mM}$ & 144 \\
\hline \multicolumn{3}{|l|}{ Detergents } \\
\hline Tween -20 & $1 \%(V / V)$ & 100 \\
\hline $\begin{array}{l}\text { Hydrogen peroxide } \\
\text { Specific Inhibitors }\end{array}$ & $1 \%(V / V)$ & 108 \\
\hline PMSF & $10 \mathrm{mM}$ & 116 \\
\hline$\beta$-mercapto ethanol & $\%(\mathrm{~V} / \mathrm{V})$ & 100 \\
\hline
\end{tabular}

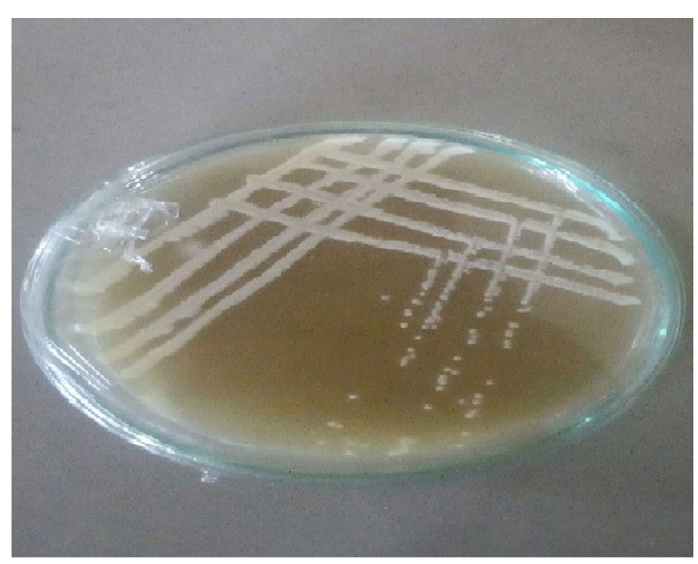

Fig. 1. Meyerozyma sp. VITPCT75 on YPPA represented in the tables and graphs indicate the arithmetic means.

\section{RESULT AND DISCUSSION}

Pectinase-producing yeast strain isolation and identification

Five yeast strains were isolated from the fermented Phyllanthus emblica fruit juice. Isolate- 1 was identified as a potential pectinase-producing strain based on the DNS assay with pectinase activity of $13.73 \mathrm{U} / \mathrm{ml} / \mathrm{min}$ and specific activity of $49.03 \mathrm{U} / \mathrm{mg}$ of protein at $25^{\circ} \mathrm{C}$ and $\mathrm{pH} 7$ using pectin as a substrate. Table 1 and Figs. 1 and 2 show the morphological and biochemical characteristics of isolate-1. The NCBI NBLAST analysis of $18 \mathrm{~S}$ and 5.8S rRNA gene sequences showed 99\% homology with other Meyerozyma sp. In the phylogenetic tree (Fig. 3), the strain lies in a separate branch, representing a novel strain. Therefore,this strain was designated as Meyerozyma sp. VITPCT75.

\section{Partial pectinase purification}

The cell-free supernatant was better concentrated at $20 \%$ saturation by all three applied methods (i.e., ammonium sulfate,

Table 4. Clarification of fruit juices by pectinase

\begin{tabular}{|c|c|c|c|}
\hline \multirow{2}{*}{$\begin{array}{l}\text { S. } \\
\text { No. }\end{array}$} & \multirow[t]{2}{*}{ Fruit juice } & \multicolumn{2}{|c|}{ Kinematic Viscosity (v) $\mathrm{m}^{2} \mathrm{Sec}^{-1}$} \\
\hline & & Test & Control \\
\hline 1. & Orange & 67.4 & 75 \\
\hline 2. & Apple & 65 & 72.4 \\
\hline 3. & Lemon & 67.8 & 76 \\
\hline 4. & Gooseberry & 66.8 & 74 \\
\hline
\end{tabular}

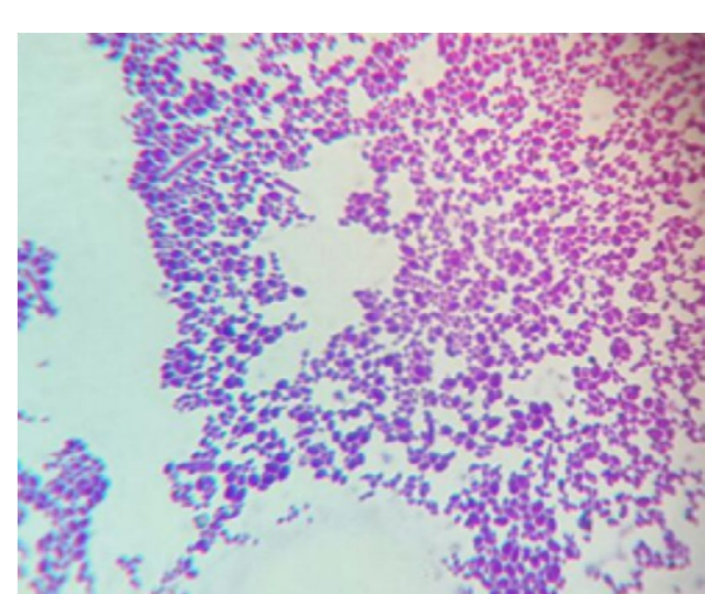

Fig. 2. Microscopic appearance of Meyerozyma sp. VITPCT75 
acetone, and ethanol precipitation) but resulted in a low yield of $8.1-9.7 \%$ and fold purification in the range of 7.2-7.8 (Table 2). The low pectinase yield could be attributed to its low molecular weight of $6 \mathrm{kDa}$, shown by SDS-PAGE, and high solubility ${ }^{32}$. Alternatively, ultrafiltration using a 5-kDa molecular weight cut-off membrane could be used to concentrate the enzyme in

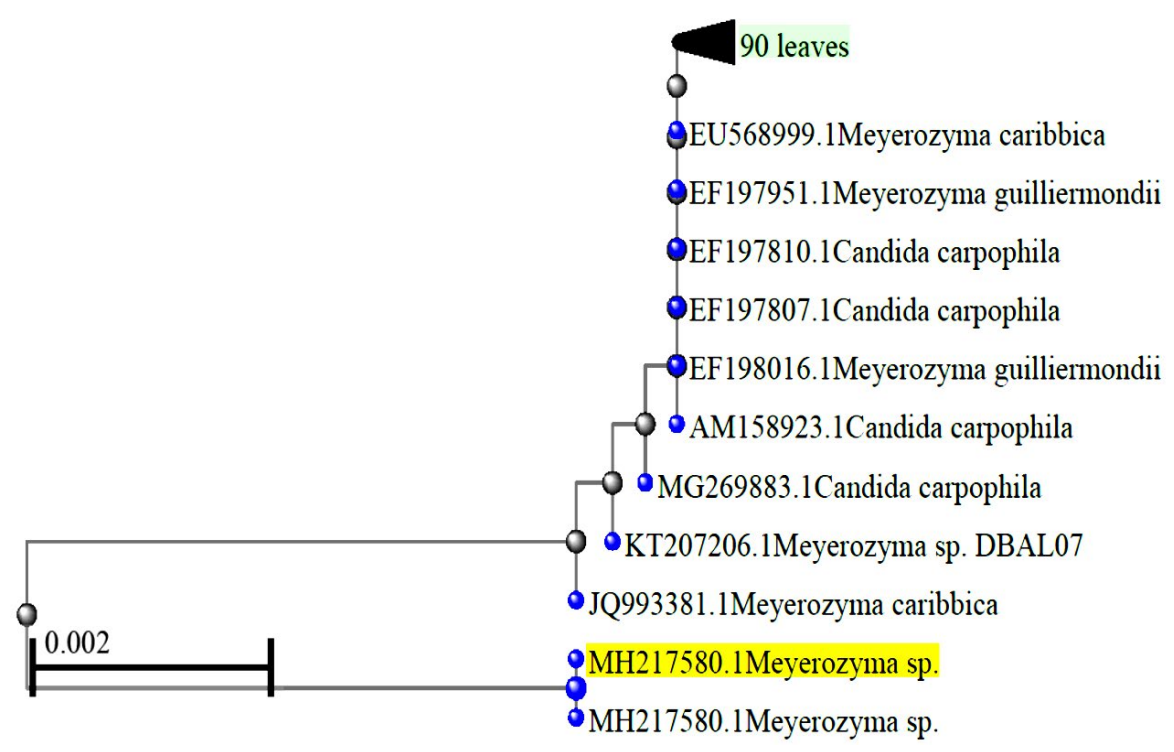

Fig. 3. Phylogenetic tree of Meyerozyma sp. VITPCT75 (MH217580)

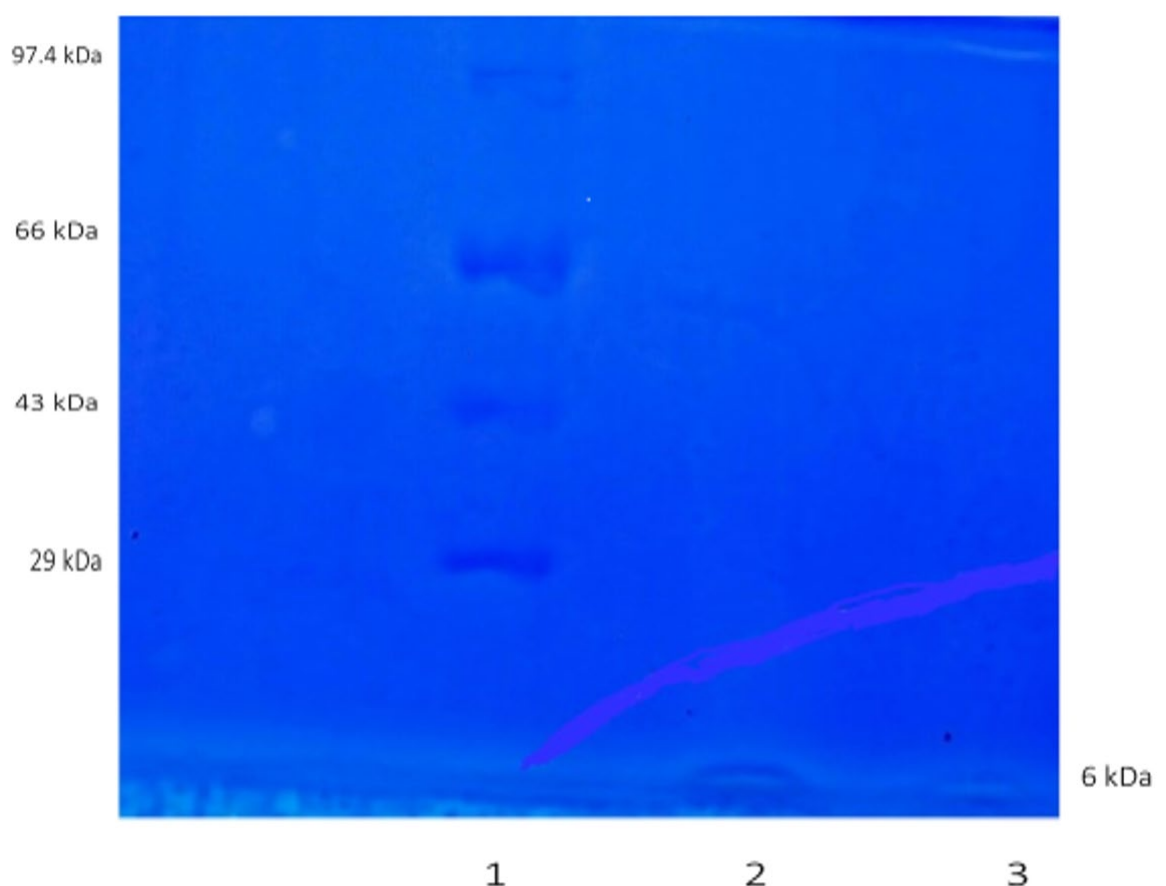

Fig. 4. SDS-PAGE of partially purified pectinase from Meyerozyma sp. VITPCT75(Lane-1: Protein Molecular weight marker, Lane-2: Acetone precipitate and Lane-3: Ethanol precipitate) 
order to achieve a better yield. However, as indicated by the specific activity and SDS-PAGE, solvent precipitation at a saturation of $20 \%$ eliminated most protein present in the cell-free extract. Moreover, for large-scale purification, ultrafiltration remains costly and cumbersome due to clogging, especially when cell-free extracts are used directly. Clients from the industrial sector, the end-users of technical enzymes, always prefer feasible and economical processes. Food industry is no exception, mostly applying enzymes obtained from GRAS organisms due to their safety. Hence, Meyerozyma sp. VITPCT75-derived pectinase could be used for pectin degradation in fruit juices after solvent precipitation.

\section{Molecular mass determination}

Figure 4 shows the SDS-PAGE results of acetone and ethanol concentrations, as well as the purified sample from ion-exchange chromatography. The molecular weight of pectinase from Meyerozyma sp. VITPCT75 was calculated to be approximately $6 \mathrm{kDa}$. The molecular mass of pectinase from various sources is reportedly in the range of $20-45 \mathrm{kDa}^{33-35}$. This is the first report of a very-low-molecularweight pectinase (6 kDa) from Meyerozyma sp. VITPCT75. The authenticity of the results was further validated by LC-MS. Low-molecularweight proteins are always preferred for industrial applications due to the ease of production, purification, and handling they allow without loss of activity. Moreover, enzyme immobilization, genetic cloning, and modifications could be performed on them without significant difficulties. Stability and pH optimum

The enzyme showed an optimum activity at $\mathrm{pH} 7$ (Fig. 5a) with a very sharp activity decrease at pH8. In contrast, it exhibited $62 \%$ of activity at
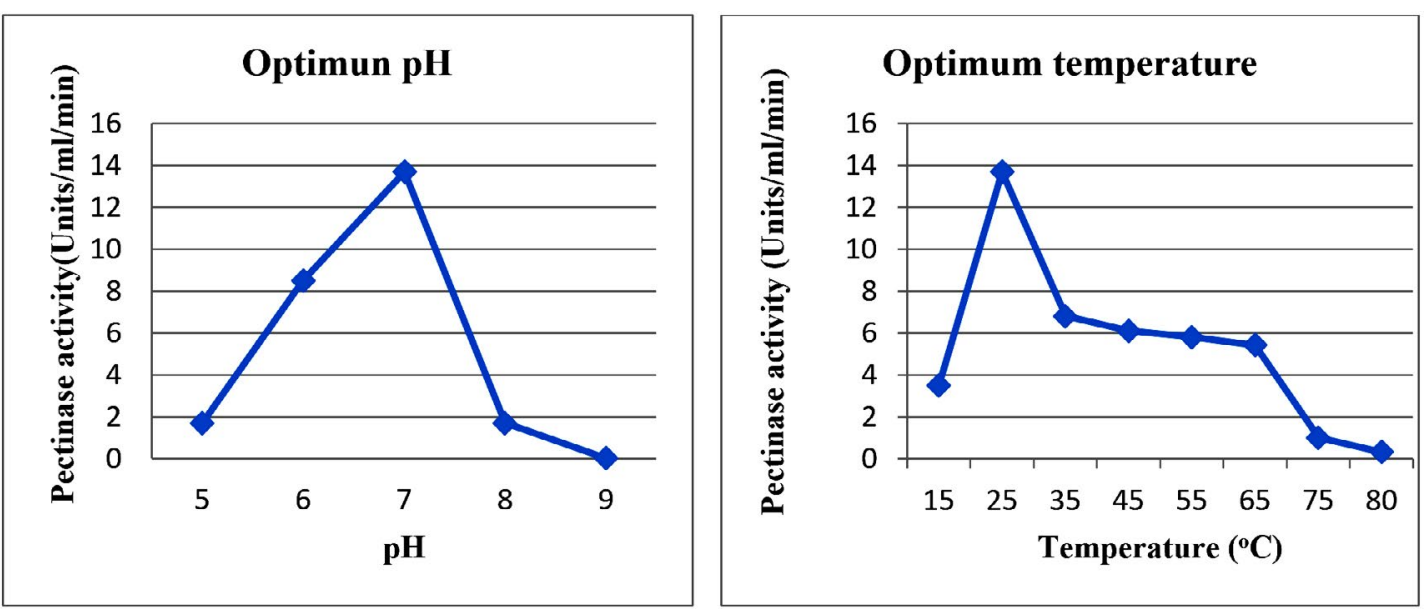

Fig. 5. Optimum temperature (a) and pH (b) of pectinase from Meyerozyma sp. VITPCT75
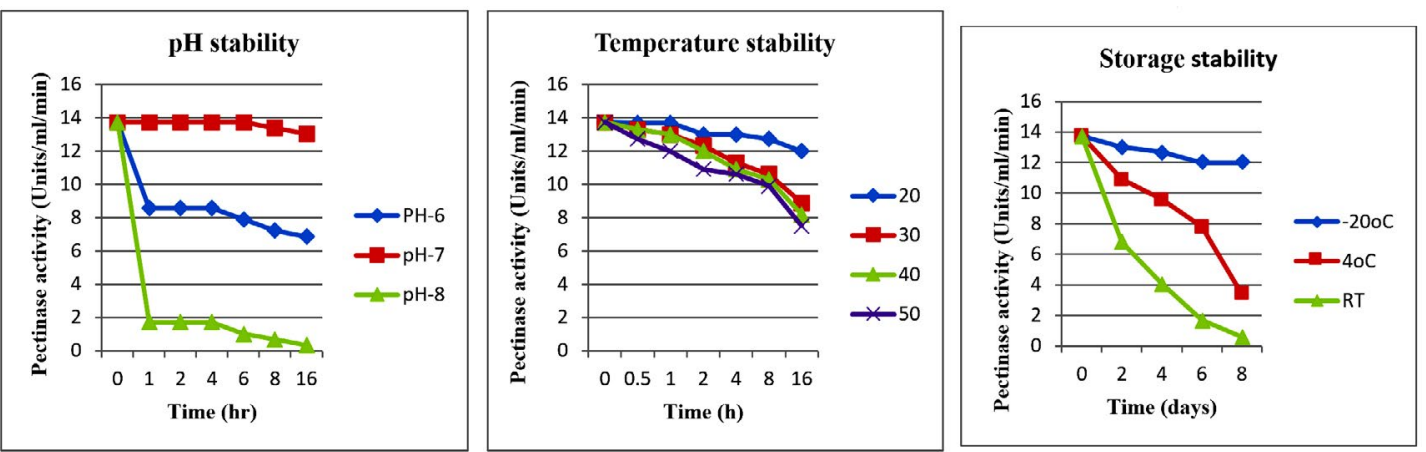

Fig. 6. Temperature (a), pH (b) and storage (c) stability of pectinase from Meyerozyma sp. VITPCT75 
pH6. This was in good agreement with the fact that yeast-derived pectinases are often active at an acidic $\mathrm{pH}^{36-38}$. Pectinase from Saccharomyces cerevisiae with optimum activity at $\mathrm{pH} 7$ was reported in an earlier study ${ }^{7}$. Studies on pectinase $\mathrm{pH}$ stability showed that the enzyme retained a maximum activity of $95 \%$ after $16 \mathrm{~h}$ of incubation at pH7 (Fig. 6A). The activity reduced significantly to its maximum at $\mathrm{pH} 6$ but remained roughly the same, indicating that the enzyme could be used successfully in pectin clarification in low-acidic fruit juices such as melon, papaya, carrot, and tomato. Temperature optimum and stability

Meyerozyma sp. VITPCT75-derived pectinase displayed an optimum activity at $25^{\circ} \mathrm{C}$, and it reduced to half at $35^{\circ} \mathrm{C}$ (Fig. 5B). The activity was maintained at approximately $45 \%$ in the temperature range of $35-65^{\circ} \mathrm{C}$ and reduced to zero at $80^{\circ} \mathrm{C}$. These results suggested that the enzyme could be used at relatively high temperatures, provided that the maximum activity was not a major constraint. Further studies reported on optimum pectinase activity within the range of $25-30{ }^{\circ} \mathrm{C}{ }^{7,39}$. The temperature stability results showed that the enzyme retained maximum activity of 95 and $90 \%$ after $2 \mathrm{~h}$ of incubation at 20 and $30{ }^{\circ} \mathrm{C}$, respectively (Fig. 6B). The activity gradually decreased after this point. The results visibly indicated that the enzyme could be used for a prolonged time with minimal inactivation.

\section{Storage stability}

Pectinase retained 95 and $79 \%$ of its maximum activity after 2 days of incubation at -20 and $4{ }^{\circ} \mathrm{C}$, respectively, and 87 and $24 \%$ after 8 days at the same storage temperatures (Fig. 6C). However, significant decrease in its activity could be observed when it was stored at $25{ }^{\circ} \mathrm{C}$. These results demonstrated that the enzyme could be stored successfully at $-20^{\circ} \mathrm{C}$ and also at $4{ }^{\circ} \mathrm{C}$ if the storage at freezing temperature would not be affordable.

\section{Metal ion and enzyme inhibitor effects}

$\mathrm{Ca}^{2} \mathrm{z}, \mathrm{Kz}, \mathrm{Cu}^{2} \mathrm{z}, \mathrm{Fe}^{2} \mathrm{z}$, and $\mathrm{Ba}^{2} \mathrm{z}$ ions led to an increase in the pectinase activity. $\mathrm{Ni}^{2} \mathrm{z}$ ions moderately, whereas $\mathrm{Mn}^{2} \mathrm{z}$ ions strongly inhibited its activity. Neither $\mathrm{Na}^{+}$and $\mathrm{Mg}^{2+}$ ions nor EDTA exhibited any enzyme inhibitory effect (Table 3 ). $\mathrm{Ca}^{2} \mathrm{z}$ ions reportedly play a vital role in pectinase confirmation maintenance ${ }^{40}$. The discrepancy in the pectinase metal ion preference indicated that the enzyme might have differential flexibility at the active site $e^{25}$. Table 3 shows that the enzyme was not inhibited by detergents. Stability in the presence of these agents is an important parameter that promotes the use of enzymes in different industries. Previous reports also stated that pectinases are stable in the presence of surfactants ${ }^{25,41,42}$. Pectinase from Meyerozyma sp. VITPCT75 was not inhibited by the serine-specific inhibitor phenyl methyl sulfonyl fluoride, resulting in the absence of a serine residue at the active site. Fruit juice clarification

Pectin is a methoxylated galacturonic acid polymer present in the cell walls of plant cells. Pectin remains suspended in fruit juices, resulting in unwanted haziness, viscosity, and turbidity. Depectinization of fruit juice using pectinases is very common to improve the filterability, storage, and consumer satisfaction of fruit juices. In the current study, the effect of pectinase from Meyerozyma sp. VITPCT75 on pectin degradation and subsequent reduction in the viscosity of fruit juices was undertaken; the results are displayed in Table 4. The enzyme treatment resulted in a significant decrease in viscosity compared to that of the control. These results were in agreement with other reports on pectinases in clarifying fruit juices ${ }^{7,43,44}$. Consequently, the enzyme could be used in the food industry for the depectinization of fruit juices. However, further studies on the byproducts and toxicity should be conducted to ascertain their potential use in industries.

\section{CONCLUSION}

This study revealed that the new yeast strain Meyerozyma sp. VITPCT75, isolated from Phyllanthus emblica, is a potential source of pectinase. The enzyme was partially purified by acetone precipitation. The molecular weight of pectinase was $6 \mathrm{kDa}$. The enzyme displayed optimum temperature and $\mathrm{pH}$ of $25^{\circ} \mathrm{C}$ and 7 and exhibited competitive stability in the close to optimum temperature and $\mathrm{pH}$ ranges. Pectinase activity was not affected by any metal ions and was not inhibited by detergents. Pectinase from Meyerozyma sp. VITPCT75 was not inhibited by PMSF, indicating the absence of serine at the active site. The enzyme significantly reduced the viscosity of representative fruit juices, suggesting that the enzyme could be used in the food industry for 
the depectinization of fruit juices. Further studies on byproducts, toxicity, and LC-MS analysis were undertaken in our laboratory.

\section{ACKNOWLEDGMENTS}

The authors thank Vellore Institute of Technology for providing the necessary facilities to carry out this research work.

\section{CONFLICT OF INTEREST}

The authors declare that there is no conflict of interest.

\section{FUNDING}

None

\section{AUTHOR'S CONTRIBUTION}

All authors listed have made a substantial, direct and intellectual contribution to the work, and approved it for publication.

\section{DATA AVAILABILITY}

All datasets generated or analyzed during this study are included in the manuscript.

\section{ETHICS STATEMENT}

Not applicable

\section{REFERENCES}

1. Kertesz ZI. Pectic enzymes. Methods Enzymol. 1955;1:158-166. doi:10.1016/0076-6879(55)01022-7

2. Latif Z, Sohail M. Molecular characterization of polygalacturonase producing Klebsiella and Staphylococcus species by $16 \mathrm{~S}$ rRNA sequencing collected from rotten fruits and vegetables. Afr J Microbiol Res. 2012; 6(46):7319-7323. doi: 10.5897/ AJMR12.957

3. Albersheim P, Jones TM, English PD. Biochemistry of the cell wall in relation to infective processes. Annu Rev Phytopathol. 1969:7(1):171-194. doi:10.1146/ annurev.py.07.090169.001131

4. Ward OP, Moo-young M, Venkat K. Enzymatic degradation of cell wall and related plant polysaccharides. Crit Rev Biotechnol. 1989;8(4):237274. doi:10.3109/07388558909148194 .

5. Baracat-Pereira MC, Coelho JL, Silva DO. Production of pectin lyase by Penicilliumgriseoroseum cultured on sucrose and yeast extract for degumming of natural fibres. Lett Appl Microbiol. 1994;18(3):127-129. doi:10.1111/j.1472-765x.1994.tb00824.x

6. Henriksson G, Akin DE, Slomczynski D, Eriksson KEL. Production of highly efficient enzymes for flax retting by Rhizomucor pusillus. J Biotechnol. 1999;68(2-3):115123. doi:10.1016/s0168-1656(98)00192-8

7. Poondla V, Bandikari R, Subramanyam R, Reddy
Obulam VS. Low temperature active pectinases production by Saccharomyces cerevisiae isolate and their characterization. Biocatal Agric Biotechnol. 2015;4(1):70-76. doi:10.1016/j.bcab.2014.09.008

8. Phugare SS, Kalyani DC, Patil AV, Jadhav JP. Textile dye degradation by bacterial consortium and subsequent toxicological analysis of dye and dye metabolites using cytotoxicity, genotoxicity and oxidative stress studies. J Hazard Mater. 2011;186(1):713-723. doi:10.1016/j. jhazmat.2010.11.049

9. Whitaker JR. Microbial pectinolytic enzymes. In: Fogarty WM, Kelly CT (Eds.), Microbial Enzymes and Biotechnology, Elsevier Science Ltd., London. 1990;133-176. doi: 10.1007/978-94-009-0765-2_4

10. Dalvi P, Anthappan P, Darade N, Kanoongo N, Adivarekar R. Amylase and pectinase from single source for simultaneous desizing and scouring. Indian Journal of Fibre and Textile Research. 2007;32:459-465.

11. Kavitha M. Cold active lipases - an update. Front Life Sci. 2016;9(3):226-238. doi : 10.1080/21553769.2016.1209134

12. Singh R, Kumar M, Mittal A, Mehta PK. Microbial enzymes: Industrial Progress in 21st century. 3 Biotech. 2016; 6:174.doi:10.1007/s13205-016-0485-8

13. Barnby FM, Morpeth FF, Pyle DL. Endopolygalacturonase production from Kluyveromyces marxianus. I. Resolution, purification, and partial characterisation of the enzyme. Enzyme Microb Technol. 1990;12(11):891897. doi:10.1016/0141-0229(90)90028-O

14. Jia JH, Wheals A. Endopolygalacturonase genes and enzymes from Saccharomyces cerevisiae and Kluyveromyces marxianus. Curr Gen. 2000;38(5):264270.doi:10.1007/s002940000160

15. Fernandez-Gonzalez M, Ubeda JF, Vasudevan TG, Otero RRC, Briones, Al. Evaluation of polygalacturonase activity in Saccharomyces cerevisiae wine strains. FEMS Microbiol Lett. 2004; 237(2): 261-266. doi:10.1111/j.1574-6968.2004.tb09705.x

16. Schwan RF, Wheals AE. The microbiology of cocoa fermentation and its role in chocolate quality. Crit Rev Food Sci Nutr. 2004; 44(4):205-221. doi:10.1080/10408690490464104

17. Luh BS, Phaff HJ. Studies on polygalacturonase of certain yeasts. Arch Biochem Biophys.1951;33(2):212-227. doi: 10.1016/0003-9861(51)90100-2

18. Vaughn RH, Jakubczyk T, MacMillan JD, Higgins TE, Dave BA, Crampton VM. Some pink yeasts associated with softening of olives. Appl Microbiol. 1969;18(5):771775. doi: 10.1128/AEM.18.5.771-775.1969

19. Da Silva EG, Borges MF, Medina C, Piccoli RH, Schwan RF. Pectinolytic enzymes secreted by yeasts from tropical fruits. FEMS Yeast Res. 2005;5(9):859-865. doi:10.1016/j.femsyr.2005.02.006

20. Merin MG, Mendoza LM, Farias ME, Morata de Ambrosini VI. Isolation and selection of yeasts from wine grape ecosystem secreting cold-active pectinolytic activity. Int J Food Microbiol. 2011;147(2):144-148. doi:10.1016/j.ijfoodmicro.2011.04.004

21. Bussink HJ, Kester HM, Visser J. Molecular cloning, nucleotide sequence and expression of the gene encoding prepro-polygalacturonasell of Aspergillus niger. FEBS Letters. 1990;273(1-2)127-130. doi: 


\subsection{6/0014-5793(90)81066-W}

22. Nasser W, Chalet F, Robert-Baudouy J. Purification and characterization of extracellular pectate lyase from Bacillus subtilis. Biochimie. 1990;72(9): 689-695. doi: 10.1016/0300-9084(90)90053-J

23. Houle V, Gagnon MC, Dube E, Hurtubise $Y$, Beauregard M. Impact of glycosylation on saccharomyces cerevisiae endopolygalacturonase pgu1 activity and stability. The Open Biotechnology Journal. 2008;2:3642. doi: $10.2174 / 1874070700802010036$

24. Sheoran S, Mandhan RP, Sudha DS, Kumar R, Sharma J. Potential application of alkaline pectinase from Bacillus subtiliss in pulp and paper industry. Appl Biochem Biotechnol. 2008;149(3):287-293. doi:10.1007/ s12010-007-8096-9

25. Oumer OJ, Abate D. Characterization of pectinase from bacillus subtilis strain btk 27 and its potential application in removal of mucilage from coffee beans. Enzyme Res. 2017;2017:7686904. doi:10.1155/2017/7686904

26. Kumar $M$, Priyadharshini AD, Kalaichelvan PT. Production and Optimization of Pectinase from Bacillus sp. MFW7 using Cassava Waste. Asian J Plant Sci Res. 2012:2(3):369-375.

27. Schwan RF, Rose AH. Polygalacturonase production by Kluyveromyces marxianus: Effect of medium composition. J Appl Bacteriol. 1994;76:62-67. doi: 10.1111/j.1365-2672.1994.tb04416.x.

28. Li Q, Coffman A, Ju LK. Development of reproducible assays for polygalacturonase and pectinase. Enzyme Microb Technol. 2015;72:42-48. doi:10.1016/j. enzmictec.2015.02.006

29. Lowry $\mathrm{OH}$, Rosebrough NJ, Farr AL, Randall RJ. Protein measurement with the Folin phenol reagent. J Biol Chem. 1951;193:265-275. doi: 10.1016/S00219258(19)52451-6

30. Laemmli UK. Cleavage of structural proteins during the assembly of the head of bacteriophage T4. Nature. 1970;227:680-685. doi: 10.1038/227680a0

31. Ackerley J, Corredig M, Wicker L. Clarification of citrus juice is influenced by specific activity of thermolabile pectin methylesterase and inactive pme-pectin complexes. J Food Sci. 2002;67:2529-2533. doi: 10.1111/j.1365-2621.2002.tb08771.x

32. Paul W. Protein precipitation using ammonium sulfate. Curr Protoc Protein Sci.2001. doi:10.1002/0471140864. psa03fs13

33. Pedrolli D, Carmona E. Purification and characterization of the exo-polygalacturonase produced by Aspergillus giganteus in submerged cultures. J Ind Microbiol Biotechnol. 2010;37:567-573. doi:10.1007/s10295010-0702-0
34. Mehrnoush A, Sarker MZI, Mustafa S, Yazid AMM. Direct purification of pectinase from mango (Mangiferaindica cv. chokanan) peel using a peg/ salt-based aqueous two phase system. Molecules. 2011;16:8419-8427. doi:10.3390/molecules16108419

35. Martos M, Paula Butiuk A, Rojas L, Hours R. Purification and characterization of a polygalacturonase produced by Wickerhamomyces anomalus. Braz Arch Biol Technol. 2014;57:587-594. doi:10.1590/S198288372014000100017

36. Ortega N, Diego S, Perez-Mateos M, Busto MD. Kinetic properties and thermal behaviour of polygalacturonase used in fruit juice clarification. Food Chem. 2004;88:209-217. doi:10.1016/j. foodchem.2004.01.035

37. Vaillant $\mathrm{F}$, Cisse $\mathrm{M}$, Chaverri $\mathrm{M}$, et al. Clarification and concentration of melon juice using membrane processes. Innov Food Sci \& Emerg Technol. 2005;6:213220. doi:10.1016/j.ifset.2004.11.004

38. Yu P, Xu C. Production optimization, purification and characterization of a heat-tolerant acidic pectinase from Bacillus sp. ZJ1407. Int J Biol Macromol. 2017;108:972980. doi:10.1016/j.ijbiomac.2017.11.012

39. Gainvors A, Nedjaoum N, Gognies S, Muzart M, Nedjma $M$, Belarbi A. Purification and characterization of acidic endo-polygalacturonase encoded by the PGL1-1 gene from Saccharomyces cerevisiae. FEMS Microbiol Lett. 2000;183:131-135. doi:10.1111/j.1574-6968.2000. tb08946.x

40. Alana A, Alkorta I, Dominguez JB, Llama MJ, Serra JL. Pectin lyase activity in a Penicillium italicum strain. Appl Environ Microbiol.1990;56:3755-3759. doi: 10.1128/ aem.56.12.3755-3759.1990

41. Beg QK, Bhushan B, Kapoor M, Hoondal GS. Production and characterization of thermostable xylanase and pectinase from Streptomyces sp. QG-11-3. J Ind Microbiol Biotechnol. 2000;24:396-402. doi:10.1038/ sj.jim. 7000010

42. Li S, Yang X, Yang S, Zhu M, Wang X. Technology prospecting on enzymes: application, marketing and engineering. Comput Struct Biotechnol J. 2012;2:e201209017. doi: 10.5936/csbj.201209017

43. Sandri IG, Fontana RC, Barfknecht M, da Silveira MM. Clarification of fruit juices by fungal pectinases. LWT-Food Sci Technol. 2011;44(10):2217-2222. doi:10.1016/j.lwt.2011.02.008

44. Avendano KA, Anguiano M, Lopez-Ortiz C, Montanez LE, Sifuentes L, Balagurusamy N. Microbial enzymes: Applications in food processing. Agro Food Ind Hi Tech. 2016;27(4):63-67. 